University of Nebraska - Lincoln

DigitalCommons@University of Nebraska - Lincoln

\title{
Congenital Transmission of Neospora Caninum in White-Tailed Deer (Odocoileus virginianus)
}

\author{
J. P. Dubey \\ USDA-ARS, Jitender.dubey@ars.usda.gov
}

M. C. Jenkins

USDA-ARS

O. C. H. Kwok

USDA-ARS, oliver.kwok@ars.usda.gov

L. R. Ferreira

USDA-ARS

S. Choudhary

USDA-ARS

See next page for additional authors

Follow this and additional works at: https://digitalcommons.unl.edu/usdaarsfacpub

Dubey, J. P.; Jenkins, M. C.; Kwok, O. C. H.; Ferreira, L. R.; Choudhary, S.; Verma, S. K.; Villena, I.; Butler, E.; and Carstensen, M., "Congenital Transmission of Neospora Caninum in White-Tailed Deer (Odocoileus virginianus)" (2013). Publications from USDA-ARS / UNL Faculty. 1336.

https://digitalcommons.unl.edu/usdaarsfacpub/1336

This Article is brought to you for free and open access by the U.S. Department of Agriculture: Agricultural Research Service, Lincoln, Nebraska at DigitalCommons@University of Nebraska - Lincoln. It has been accepted for inclusion in Publications from USDA-ARS / UNL Faculty by an authorized administrator of DigitalCommons@University of Nebraska - Lincoln. 


\section{Authors}

J. P. Dubey, M. C. Jenkins, O. C. H. Kwok, L. R. Ferreira, S. Choudhary, S. K. Verma, I. Villena, E. Butler, and M. Carstensen 


\title{
Congenital transmission of Neospora caninum in white-tailed deer (Odocoileus virginianus)
}

\author{
J.P. Dubey ${ }^{\mathrm{a}, *}$, M.C. Jenkins ${ }^{\mathrm{a}}$, O.C.H. Kwok ${ }^{\mathrm{a}}$, L.R. Ferreira ${ }^{\mathrm{a}}$, S. Choudhary ${ }^{\mathrm{a}}$, \\ S.K. Verma ${ }^{\mathrm{a}}$, I. Villena ${ }^{\mathrm{b}}$, E. Butler $^{\mathrm{c}}$, M. Carstensen ${ }^{\mathrm{c}}$ \\ a United States Department of Agriculture, Agricultural Research Service, Beltsville Agricultural Research Center, Animal Parasitic \\ Diseases Laboratory, Beltsville, MD 20705-2350, USA \\ b Laboratory of Parasitology-Mycology, National Reference Centre on Toxoplasmosis, Biological Resources Centre Toxoplasma, Hospital \\ Maison Blanche, 45 rue Cognac-Jay, 51092 Reims Cedex, France \\ ' Division of Wildlife, Minnesota Department of Natural Resources, 5463-C West Broadway, Forest Lake, MN 55025, USA
}

\section{A R T I C L E I N F O}

\section{Article history:}

Received 28 January 2013

Received in revised form 25 February 2013

Accepted 4 March 2013

\section{Keywords:}

Neospora caninum

White-tailed deer

Odocoileus virginianus

Congenital

Neospora agglutination test

\begin{abstract}
A B S T R A C T
Neosporosis is an important cause of bovine abortion worldwide. Many aspects of transmission of Neospora caninum in nature are unknown. The white-tailed deer (Odocoileus virginianus) is considered one of the most important wildlife reservoirs of $N$. caninum in the USA. During the hunting seasons of 2008, 2009, and 2010, brains of 155 white-tailed deer fetuses were bioassayed in mice for protozoal isolation. Viable N. caninum (NcWTDMn1, NcWTDMn2) was isolated from the brains of two fetuses by bioassays in mice, and subsequent propagation in cell culture. Dams of these two infected fetuses had antibodies to $N$. caninum by Neospora agglutination test at 1:100 serum dilution. DNA obtained from culture-derived N. caninum tachyzoites of the two isolates with Nc5 PCR confirmed diagnosis. Results prove congenital transmission of $N$. caninum in the white tailed deer for the first time.
\end{abstract}

Published by Elsevier B.V.

\section{Introduction}

Neospora caninum is a major cause of bovine abortion worldwide (Dubey, 2003; Dubey and Schares, 2011). Its life cycle involves canids as definitive hosts and ruminants as intermediate hosts. A sylvatic cycle between canids (feral dogs, wolves and coyotes) and game is thought to be important in the biology of $N$. caninum (McAllister et al., 1998; Gondim et al., 2004a; Dubey et al., 2011). The white-tailed deer (WTD) is one of the most important reservoir hosts of $N$. caninum infection based on different serologic surveys (Dubey et al., 1999, 2007, 2009, 2011; Lindsay et al., 2002; Gondim et al., 2004b; Anderson et al., 2007) and viable $N$. caninum has been isolated from brains of adult WTD (Vianna et al., 2005). The high seroprevalence of $N$. caninum in fawns and the lack of association between

\footnotetext{
* Corresponding author. Tel.: +1 301504 8128; fax: +1 3015049222

E-mail address: Jitender.dubey@ars.usda.gov (J.P. Dubey).
}

seroprevalence of $N$. caninum antibodies and the age of deer suggest that $N$. caninum might be congenitally transmitted in deer, similar to bovine infections (Dubey et al., 1999). Although $N$. caninum-like organisms were found in the brain of a stillborn Eld's deer (Cervus eldi siamensis, Dubey et al., 1996) and in the brain of 3-week old fallow deer (Dama dama, Soldati et al., 2004) and tissues of a two month old black tailed deer (Odocoileus hemionus columbianus, Woods et al., 1994), there is no report of clinical neosporosis and isolation or demonstration of $N$. caninum in tissues of fetal or neonatal WTD. Here, we report first definitive isolation of viable $N$. caninum from tissues of fetuses from WTD from Minnesota.

\section{Materials and methods}

\subsection{Naturally infected deer}

The WTD from Minnesota were killed in the winter/spring (February-April) of 2008, 2009, and 
2010. These deer were shot as part of a program to reduce wild deer potentially infected with bovine tuberculosis in a $200 \mathrm{~km}^{2}$ area centered at Skime, Minnesota (Dubey et al., 2008). Blood or clot was collected from the heart or chest cavity of 485 deer soon after death (Table 1), and centrifuged. Serum samples from dams and brains from fetuses were sent with cold packs to the Animal Parasitic Diseases Laboratory (APDL), Beltsville, Maryland for Neospora testing.

\subsection{Serological examination}

Neospora caninum agglutination test (NAT) was used to detect antibodies to $N$. caninum. The NAT was performed with mouse-derived whole tachyzoites antigen as described by Romand et al. (1998). The antigen was made at the Laboratory of Parasitology-Mycology, National Reference Center on Toxoplasmosis, Biological Resources Center Toxoplasma, Hospital Maison Blanche, Reims Cedex, France as described by Romand et al. (1998). To conserve antigen, deer sera were screened only at 1:100 serum dilution. Mouse sera were tested at 1:25 serum dilution.

\subsection{Bioassays of deer tissues for isolation of N. caninum}

The Swiss Webster (SW) outbred immunocompetent mouse is a poor host for $N$. caninum (Dubey and Lindsay, 1996). Before the commercial availability of KO mice, cortisonized SW mice were used to propagate $N$. caninum (Dubey and Lindsay, 1996).

SW mice were cortisonized by oral medication with dexamethasone, $10 \mu \mathrm{g} / \mathrm{ml}$, ad lib., in drinking water from 0 day to 21 days p.i. (Romand et al., 1998)

Brains of 155 fetuses were bioassayed. Deer fetal brains were homogenized individually in approximately 10 volumes of aqueous $0.85 \% \mathrm{NaCl}$ (saline) in a blender as described (Dubey et al., 2008; Dubey, 2010). The homogenate was filtered through gauze, centrifuged at $1400 \times g$ for $10 \mathrm{~min}$. The sediment was suspended in $3-5 \mathrm{ml}$ of antibiotic saline (2000 units penicillin, $200 \mu \mathrm{g}$ streptomycin per $\mathrm{ml}$ of saline) and $0.5-1.0 \mathrm{ml}$ of the suspension was inoculated subcutaneously into $\mathrm{KO}$ and/or SW cortisonized mice. The $\mathrm{KO}$ and SW/dexamethasone treated mice that died or were euthanized when ill were examined for protozoa. Survivors were bled two months later and 1:25 dilution of their sera were examined for antibodies to $N$. caninum. Tissues of mice that died due to protozoal infection were sub-inoculated in to $\mathrm{KO}$ mice and or SW/cortisonized (Table 1 ).

\subsection{Necropsy and immunohistological examination}

Samples of all major organs of mice were fixed in $10 \%$ buffered formalin. Paraffin-embedded tissues were sectioned at $5 \mu \mathrm{m}$ and examined after staining with hematoxylin and eosin. Immunohistochemistry was performed on paraffin-embedded sections using reagents and methods described previously by Lindsay and Dubey (1989).

\subsection{In vitro cultivation}

Tissues from mice with demonstrable Neospora tachyzoites were homogenized in RPMI-1640 medium supplemented with L-glutamine, and seeded on to CV1 (derived from Cercopithecus aethiops monkey kidneys) cells. The cell cultures were observed microscopically for growth of protozoa for 3 months.

\subsection{DNA extraction and PCR amplification}

A competitive PCR method was used (Liddell et al., 1999). DNA from cell cultures inoculated with $N$. caninum isolated from mouse lung were extracted using the QIAamp Mini DNA kit (QIAGEN Inc., Valencia, CA, USA), and subjected to PCR amplification of the Nc5 gene sequence (Kaufmann et al., 1996; Müller et al., 1996; Liddell et al., 1999) using PrimeStar amplification kit (Clontech Laboratories, Inc., Mountain View, CA, USA). PCR products were analyzed by acrylamide gel electrophoresis followed by EtBr staining, and visualization and capture on a GelLogic 200 Imaging System (Eastman Kodak, Hemel Hempstead, U.K.). The Nc5 target amplification product was isolated using a QIAquick PCR Purification Kit (QIAGEN Inc.), concentrated by ethanol precipitation, dried at room temperature, suspended in sterile water, and then inserted into pGEM-T Easy cloning vector using manufacturer's recommendations (Novagen, San Diego, CA, USA). The ligation mixtures were introduced into Escherichia coli DH5 using standard procedures (Hanahan, 1983), followed by colony PCR analysis (Güssow and Clackson, 1989). At least two separate PCR amplifications were conducted for each DNA sample, and a minimum of three recombinant clones were evaluated for each amplification product. Colony amplification reactions exhibiting the expected size product by polyacrylamide gel electrophoresis were then subjected to sequence analysis using M13 forward and reverse primers, and a Big Dye Terminator v3.1 Cycle Sequencing Kit (Applied Biosystems, Carlsbad, CA, USA). DNA sequences were verified as Nc5 by BLAST-N analysis of sequences deposited in the GenBank database.

Table 1

$N$ caninum prevalence in white-tailed deer from Minnesota.

\begin{tabular}{lccc}
\hline Year & Adult deer sampled & $\begin{array}{l}\text { NAT positivity of adult deer } \\
(\geq 1: 100)\end{array}$ & $\begin{array}{l}\text { No. of fetuses bioassayed (from } \\
\text { N. caninum seopositive dams) }\end{array}$ \\
\hline 2008 & 175 & $15(8.5 \%)$ & $22(3)$ \\
2009 & 213 & $33(15.4 \%)$ & $100(33)$ \\
2010 & 97 & $32(32.9 \%)$ & $33(21)$ \\
Total & 485 & $80(16.5 \%)$ & 1 \\
\hline
\end{tabular}


Table 2

Isolation of N. caninum from white-tailed deer fetuses from Minnesota.

\begin{tabular}{|c|c|c|c|c|c|c|}
\hline \multicolumn{2}{|l|}{ Dam } & \multicolumn{4}{|l|}{ Fetus } & \multirow[t]{3}{*}{ N. caninum strain } \\
\hline \multirow[t]{2}{*}{ No. } & \multirow[t]{2}{*}{ Date shot } & \multicolumn{2}{|c|}{ Initial bioassay in mice ${ }^{a}$} & \multicolumn{2}{|c|}{ Sub-inoculation } & \\
\hline & & SW & KO & SW & KO & \\
\hline 8776 & $4-2008$ & $0 / 2^{b}$ & $2 / 2^{c}$ & Not done & $2 / 2^{d}$ & NcWTDMn1 \\
\hline 207 & $3-2009$ & Not done & $2 / 3^{e}$ & $2 / 2^{f}$ & Not done & NcWTDMn2 \\
\hline
\end{tabular}

a SW, Swiss Webster outbred mice treated orally with dexamethasone; KO, interferon gamma gene knockout mice. Figures show no. of mice infected with $N$. caninum/no. of mice inoculated.

b Mice were killed day 53 p.i. in good health and were not infected.

c One KO mouse died day 46 p.i. and was discarded because it was autolysed. The second mouse died day 49 p.i. The mouse was paralyzed and had antibodies to $\mathrm{N}$. caninum. Its lung and brain tissue homogenate was subinoculated into $2 \mathrm{KO}$ mice.

d One KO mouse died day 32 p.i. and was discarded because of autolysis. The second KO mouse was euthanized day 32 p.i. because it was sick. Its brain and lung homogenate was seeded on to cell culture flask and $N$. caninum was successfully propagated. $N$. caninum was demonstrated immunohistochemically in pancreas, heart and brain of the mouse.

e One KO mouse died day 27 p.i. Tachyzoites were found in its lung and lung homogenate was subinoculated in to two KO mice and onto cell culture. $N$. caninum was successfully propagated in to cell culture. The second KO mouse was euthanized on day 29 p.i. Antibodies to $N$. caninum were found in its serum. $N$. caninum was demonstrated immunohistochemically in lung, heart and brain of the mouse. The third KO was not infected and was killed day 48 p.i.

f The mice remained asymptomatic and were killed day 91 p.i. Tissue cysts were not found in the brains but antibodies to $N$. caninum were detected in their serum samples.

\subsection{Ethics}

All experiments were performed according to the Animal Experimentation Protocols by all institutions involved.

\section{Results}

Antibodies to N. caninum were found in 80 (16.5\%) of 485 adult deer (Table 1 ). Viable $N$. caninum was isolated in mice and cell culture from brains of two of 155 fetuses from two dams (Table 2). These two $N$. caninum isolates were from two of 57 dams positive for Neospora antibodies.

$N$. caninum was demonstrated in tissues of infected mice by imunohistochemical staining with $N$. caninum antibodies. By PCR, serological and immunohistochemical testing there was no evidence of coinfection with Toxoplasma gondii (data not shown).

Nc5 PCR analysis of both isolates confirmed that tachyzoites from cell culture of mouse lung were $N$. caninum. Amplified products were in the expected size range (Fig. 1) for both isolates. Alignment of the Nc5 sequences obtained by DNA sequencing of the amplification products showed greater than $99 \%$ similarity to various Nc5 sequences in GenBank, further corroborating the histological and PCR findings.

\section{Discussion}

Control of bovine neosporosis in the USA has been problematic, and may be due to the presence of the $N$. caninum in wildlife reservoirs. In some regions of the USA there is an overpopulation of WTD and coyotes, and both deer and coyotes are moving toward the urban areas (Dubey et al., 2007). Seroprevalence of $N$. caninum in deer varies with the serologic test, cut-off value, and the region (Dubey and Schares, 2011). In the USA, antibodies to N. caninum were found in $40.5 \%$ of 400 (Dubey et al., 1999), and $46.5 \%$ of 43 (Gondim et al., 2004b) WTD from Illinois, 20\% of 150 WTD from Minnesota in one survey (Gondim et al., 2004b) and $70.9 \%$ of 62 WTD in another survey (Dubey et al., 2009),
$48 \%$ of 305 deer from 14 southwestern states (Lindsay et al., 2002), $48 \%$ of 23 from Missouri, and 20\% of 147 WTD from Wisconsin (Anderson et al., 2007). Although data in these surveys are not comparable because of different serological tests and different cut-off values used, they do indicate that at least $20 \%$ of WTD have been exposed to N. caninum.

In the present study $N$. caninum was isolated from 2 of 155 fetuses (1.3\%), and only 57 of these fetuses were from $N$. caninum seropositive dams. The low isolation rate of $N$. caninum is probably related to the difficulties of isolating N. caninum from animal tissues.

The mode of transmission of $N$. caninum differs with respect to hosts. Although fecal transmission by oocysts is essential for introduction of the parasite in cattle herds, epidemiological data indicate that vertical/congenital transmission is highly efficient in cattle to

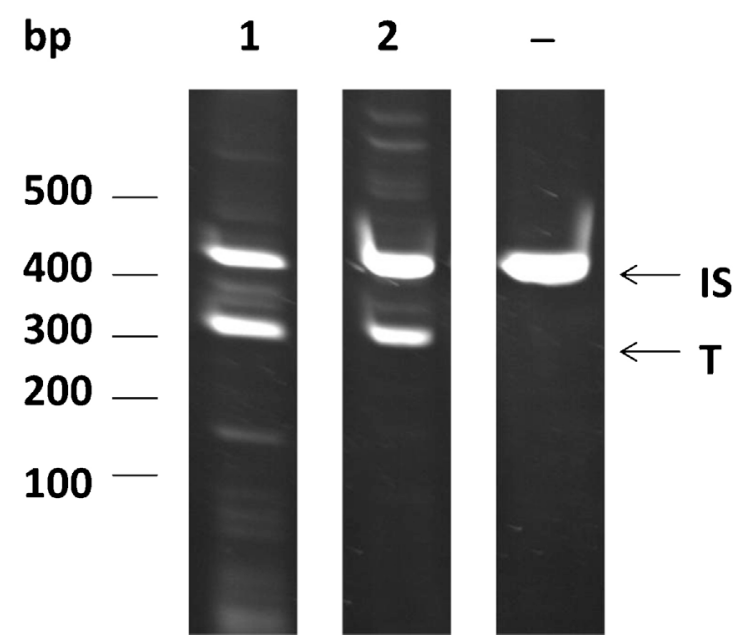

Fig. 1. Amplification products from competitive Nc5 PCR analysis of tachyzoite DNA from cell cultures infected with N. caninum from mouse brain. The fetal brains from WTD were the initial source of the parasite and that a competitive PCR was performed. T, Nc5 target; IS, Nc5 internal standard; bp, 100 bp standards. 
maintain the infection (Dubey et al., 2007; Dubey and Schares, 2011). Much of the evidence for transplacental transmission in cattle is derived from serological surveys using pre-colostral samples; however, this method is impractical in wildlife. Results of the present study indicate that transplacental transmission occurs naturally in the WTD but frequency remains to be determined.

Hundreds of thousands of WTD are harvested by hunters and killed in traffic accidents yearly. Unless removed from the environment, the WTD carcass tissues are potential source of infection for wild and domestic dogs, wolves, and coyotes that can shed $N$. caninum oocysts.

\section{Conflict of interest}

None.

\section{References}

Anderson, T., Dejardin, A., Howe, D.K., Dubey, J.P., Michalski, M.L., 2007. Neospora caninum antibodies detected in Midwestern white-tailed deer (Odocoileus virginianus) by Western blot and ELISA. Vet. Parasitol. $145,152-155$.

Dubey, J.P., Lindsay, D.S., 1996. A review of Neospora caninum and neosporosis. Vet. Parasitol. 67, 1-59.

Dubey, J.P., Rigoulet, J., Lagourette, P., George, C., Longeart, L., LeNet, J.L., 1996. Fatal transplacental neosporosis in a deer (Cervus eldi siamensis). J. Parasitol. 82, 338-339.

Dubey, J.P., Hollis, K., Romand, S., Thulliez, P., Kwok, O.C.H., Hungerford, L., Anchor, C., Etter, D., 1999. High prevalence of antibodies to Neospora caninum in white-tailed deer (Odocoileus virginianus). Int. J. Parasitol. 29, 1709-1711.

Dubey, J.P., 2003. Neosporosis in cattle. J. Parasitol. 89 (Suppl.), S42-S56.

Dubey, J.P., Schares, G., Ortega-Mora, L.M., 2007. Epidemology and control of neosporosis and Neospora caninum. Clin. Microbiol. Rev. 20, 323-367.

Dubey, J.P., Velmurugan, G.V., Ulrich, V., Gill, J., Carstensen, M., Sundar, N., Kwok, O.C.H., Thulliez, P., Majumdar, D., Su, C., 2008. Transplacental toxoplasmosis in naturally-infected white-tailed deer: isolation and genetic characterization of Toxoplasma gondii from foetuses of different gestational ages. Int. J. Parasitol. 38, 1057-1063.

Dubey, J.P., Jenkins, M.C., Kwok, O.C.H., Zink, R.L., Michalski, M.L., Ulrich, V., Carstensen, M., Thulliez, P., 2009. Seroprevalence of Neospora caninum and Toxoplasma gondii antibodies in white-tailed deer (Odocoileus virginianus) from Iowa and Minnesota using four serologic tests. Vet. Parasitol. 161, 330-334.

Dubey, J.P., 2010. Toxoplasmosis of Animals and Humans, 2nd ed. CRC Press, Boca Raton, FL1-313.

Dubey, J.P., Schares, G., 2011. Neosporosis in animals - the last five years. Vet. Parasitol. 180, 90-108.

Dubey, J.P., Jenkins, M.C., Rajendran, C., Miska, K., Ferreira, L.R., Martins, J., Kwok, O.C.H., Choudhary, S., 2011. Gray wolf (Canis lupus) is a natural definitive host for Neospora caninum. Vet. Parasitol. 181, 382-387.

Gondim, L.F.P., McAllister, M.M., Pitt, W.C., Zemlicka, D.E., 2004a. Coyotes (Canis latrans) are definitive hosts of Neospora caninum. Int. J. Parasitol. 34, 159-161.

Gondim, L.F.P., McAllister, M.M., Mateus-Pinilla, N.E., Pitt, W.C., Mech, L.D Nelson, M.E., 2004b. Transmission of Neospora caninum between wild and domestic animals. J. Parasitol. 90, 1361-1365.

Güssow, D., Clackson, T., 1989. Direct clone characterization from plaques and colonies by the polymerase chain reaction. Nucleic Acids Res. 17, 4000.

Hanahan, D., 1983. Studies on the transformation of Escherichia coli with plasmids. J. Mol. Biol. 166, 557-580.

Kaufmann, H., Yamage, M., Roditi, I., Dobbelaere, D., Dubey, J.P., Holmdahl, O.J., Trees, A., Gottstein, B., 1996. Discrimination of Neospora caninum from Toxoplasma gondii and other apicomplexan parasites by hybridization and PCR. Mol. Cell. Probes 10, 289-297.

Liddell, S., Jenkins, M.C., Dubey, J.P., 1999. A competitive PCR assay for quantitative detection of Neospora caninum. Int. J. Parasitol. 29, 1583-1587.

Lindsay, D.S., Dubey, J.P., 1989. Immunohistochemical diagnosis of Neospora caninum in tissue sections. Am. J. Vet. Res. 50, 1981-1983.

Lindsay, D.S., Little, S.E., Davidson, W.R., 2002. Prevalence of antibodies to Neospora caninum in white-tailed deer, Odocoileus virginianus, from the Southeastern United States. J. Parasitol. 88, 415-417.

McAllister, M.M., Dubey, J.P., Lindsay, D.S., Jolley, W.R., Wills, R.A., McGuire, A.M., 1998. Dogs are definitive hosts of Neospora caninum. Int. J. Parasitol. 28, 1473-1478.

Müller, N., Zimmermann, V., Hentrich, B., Gottstein, B., 1996. Diagnosis of Neospora caninum and Toxoplasma gondii infection by PCR and DNA hybridization immunoassay. J. Clin. Microbiol. 34, 2850-2852.

Romand, S., Thulliez, P., Dubey, J.P., 1998. Direct agglutination test for serologic diagnosis of Neospora caninum infection. Parasitol. Res. 84, 50-53.

Soldati, S., Kiupel, M., Wise, A., Maes, R., Botteron, C., Robert, N., 2004. Meningoencephalomyelitis caused by Neospora caninum in a juvenile fallow deer (Dama dama). J. Vet. Med. A 51, 280-283.

Vianna, M.C.B., Sreekumar, C., Miska, K.B., Hill, D.E., Dubey, J.P., 2005. Isolation of Neospora caninum from naturally infected white-tailed deer (Odocoileus virginianus). Vet. Parasitol. 129, 253-257.

Woods, L.W., Anderson, M.L., Swift, P.K., Sverlow, K.W., 1994. Systemic neosporosis in a California black-tailed deer (Odocoileus hemionus columbianus). J. Vet. Diagn. Invest. 6, 508-510. 